\title{
Comparison of Clomiphene Citrate and Low Dose Recombinant FSH for Induction of Ovulation in Infertile Women with Polycystic Ovary Syndrome
}

\author{
Polikistik Over Sendromlu İnfertil Kadınlarda \\ Ovulasyon İndüksiyonunda Klomifen Sitrat ile \\ Düşük Doz Rekombinant FSH'nin Karşılaştırılması
}

\section{Yeliz AKÇELIK, ${ }^{a}$ Ebru ÇÖĞENDEZ, ${ }^{b}$ Dilek BENK ŞiLFELER, ${ }^{\circ}$ Meryem EKEN, Selda KARAKAYA ${ }^{a}$}

${ }^{a}$ Clinic of Obstetrics and Gynecology, Pendik Region Hospital, ${ }^{\mathrm{b}} \mathrm{Clinic}$ of Obstetrics and Gynecology, Zeynep Kamil Training and Research Hospital, 'Department of Obstetrics and Gynecology, Mustafa Kemal University Faculty of Medicine, Hatay

Geliș Tarihi/Received: 23.07 .2014 Kabul Tarihi/Accepted: 07.01.2015

Yazışma Adresi/Correspondence: Meryem EKEN

Zeynep Kamil Training and

Research Hospital,

Clinic of Obstetrics and Gynecology, İstanbul,

TÜRKIYE/TURKEY

meryemkurek@yahoo.com doi: 10.5336/gynobstet.2014-41444

Copyright $\odot 2015$ by Türkiye Klinikleri

\begin{abstract}
Objective: In our study, we aim to compare the treatment success and complication rates of clomiphene citrate (CC) and gonadotopins ( $\mathrm{r}-\mathrm{FSH}$ ) using low dose step-up protocol, which are both frequently used as induction of ovulation protocols in patients with polycystic ovary syndrome (PCOS). Material and Methods: 138 patients with PCOS who presented at our infertility outpatient clinic and underwent ovulation induction were included in the study. Diagnosis of PCOS was reached using Rotterdam Criteria after exclusion of other etiological factors. Induction of ovulation was performed on 86 patients with $\mathrm{CC}$ and 52 patients with recombinant FSH $(\mathrm{r}-\mathrm{FSH})$ using low dose step-up protocol. Clomiphene citrate $(\mathrm{n}=86)$ was administered between the $5^{\text {th }}$ and $9^{\text {th }}$ days of the menstrual cycle with an initial dose of $50 \mathrm{mg} /$ day. Ovulation induction with $\mathrm{r}$-FSH $(\mathrm{n}=52)$ was done using low dose step-up protocol with an initial dose of 75 IU/day. Results: Number of follicles was significantly higher in patients in the r-FSH group $(\mathrm{p}=0.01)$. The incidence of ovarian hyperstimulation syndrome (OHSS) did not differ significantly among the groups $(\mathrm{p}=0.487)$. Also there was no significant difference in pregnancy ratios between two groups $(\mathrm{p}=0.064$ ). Pregnancy ratios in the $\mathrm{r}-\mathrm{FSH}$ and $\mathrm{CC}$ groups were found to be $12.5 \%$ and $5.9 \%$, respectively. Of the pregnant subjects in the $\mathrm{CC}$ groups $(\mathrm{n}=8)$, one had a miscarriage at $10^{\text {th }}$ gestational week; one live birth and 1 stillbirth was observed while pregnancies of the remaining $5(62.5 \%)$ were maintained. Within the r-FSH group, where 16 subjects got pregnant, 6 live births (37.5\%) and 1 stillbirth (6.3\%) observed, and 2 subjects (12.5\%) had first trimester abortus. 7 subjects of this group $(43.8 \%$ ) had their pregnancies maintained, while two of these were multiple pregnancies (one couplet and one triplet). Conclusion: Clomiphene citrate should be the first line treatment in the ovulation induction of patients with PCOS due to its low costs, easier patient monitorization (oral use), and lower risk of multiple pregnancies and OHSS. On the other hand, we think that administration of r-FSH in PCOS patients using low dose step-up protocol is a safe approach. Therefore, it should be the treatment of choice in patients who do not respond to CC of maximum dosage or for 6 or more cycles.
\end{abstract}

Key Words: Clomiphene; gonadotropins; infertility; polycystic ovary syndrome

ÖZET Amaç: Calıșmamızın amacı, polikistik over sendromlu (PCOS) hastalarda ovulasyon indüksiyon protokolü olarak sıklıkla kullanılan klomifen sitrat (CC) ve düşük doz step up protokolü ile uygulanan gonadotropinlerin (rFSH) tedavi başarısı ile komplikasyon oranları açısından karşılaştırmaktır. Gereç ve Yöntemler: İnfertilite polikliniğimize başvuran ve ovulasyon indüksiyonu yapılan 138 PCOS olgusu çalışmaya dâhil edildi. PCOS tanısı diğer etyolojik faktörleri dışladıktan sonra Rotterdam Kriterleri ile değerlendirilerek konuldu. 86 hastaya CC, 52 hastaya rekombinant FSH (r-FSH) ile düşük doz step-up protokolü uygulanarak ovulasyon indüksiyonu yapıldı. Klomifen sitrat ( $\mathrm{n}=86$ ) menstrüel siklusun 5-9. günleri arasında günlük $50 \mathrm{mg}$ başlangıç dozunda uygulandı. $\mathrm{r}-$ FSH ( $\mathrm{n}=52$ ) ile ovulasyon indüksüyonu düşük doz step-up protokolü ile (75 IU/gün başlangıç dozu) stimülasyon yapıldı. Bulgular: $r-F S H$ ile indüksiyon uygulanan hastalarda folikül sayısı anlamlı olarak daha fazlaydı $(\mathrm{p}=0,01)$. Ovaryen hiperstimülasyon sendromu (OHSS) insidansı gruplar arasında anlamlı fark göstermedi ( $\mathrm{p}=0,487)$. Gruplar arasında gebelik oranları istatistiksel olarak anlamlı bir fark göstermedi $(\mathrm{p}=0,064)$. Gebelik oranları r-FSH ve CC gruplarında sırasıly $\% 12,5$ ve $\% 5,9$ olarak bulundu. CC grubundaki $(\mathrm{n}=8)$ gebe kalan hastalardan beşinin $(\% 62,5)$ gebeliği devam ederken, bir hasta 10. gebelik haftasında düşük yaptı. Bir olgu canlı doğum bir olgu da ölü doğum yaptı. r-FSH grubunda ise gebe kalan 16 olgudan $6(\% 37,5)$ 'sı canlı doğum, $1(\% 6,3)$ 'i ölü doğum yapmıs olup 2 hastada $(\% 12,5)$ birinci trimesterde abortus meydana gelmiştir. Bu grupta $7(\% 43,8)$ hastanın gebeliğinin devam ettiğ̣i görüldü. Gebeliği devam eden olguların ikisinde çoğul gebelik saptandı (biri ikiz, biri üçüz). Sonuç: Düşük maliyet, kolay hasta takibi (oral kullanım), düşük çoğul gebelik ve ovaryen hiperstimülasyon sendromu riskleri nedeniyle polikistik over sendromlu hastaların ovulasyon indüksiyonunda klomifen sitrat öncelikli tedavi olarak uygulanmalıdır. Öte yandan PCOS'li hastalarda r-FSH'nin düşük doz step-up protokolü ile uygulanmasının güvenli olduğunu düşünmekteyiz. Bu sebeple maksimum doz ve 6 ya da daha fazla siklus boyunca CC'ye cevap vermeyen olgularda seçilecek ilk tedavi modalitesi olması gerektiği kanaatindeyiz.

Anahtar Kelimeler: Klomifen; gonadotropinler; infertilite; polikistik over sendromu

Turkiye Klinikleri J Gynecol Obst 2015;25(1):19-26 
$\mathrm{F}$ or more than 150 years, attempts have been made to understand the clinical significance and pathophysiology of polycystic ovaries and polycystic ovary syndrome (PCOS). PCOS was defined by Dr. Stein and Leventhal in 1935 as the coexistence of polycystic ovaries, amenorrhea, hirsutismus and obesity and is the most common endocrinopathy of women in their reproductive ages with a prevalence of approximately $4-8 \% .^{1,2}$

Infertility affects $40 \%$ women with PCOS, making it the most common cause of anovulatory infertility. ${ }^{3}$

The number of primordial follicles observed in the ovaries of women with PCOS is normal while the numbers of primary and secondary follicles are significantly increased. Due to an imbalance in normal follicular development, follicles stop growing as they reach a diameter of 4 to $8 \mathrm{~mm}$. Dominant follicle does not develop and ovulation does not occur. ${ }^{3,4}$

Ovulation induction should be concluded in delivery of a single baby and the complications of a multiple pregnancy and ovarian hyperstimulation syndrome should be avoided.

Clomiphene citrate is the first choice for ovulation induction in women with PCOS. ${ }^{5}$ With clomiphene treatment, ovulation rate per cycle is 70 to $85 \%$ and the cumulative live birth rate rises up to 50 to $60 \%$ in a total of six cycles. ${ }^{6}$ Second line therapy includes exogenous gonadotropins (FSH) and laparoscopic ovarian drilling. ${ }^{7}$

Primary aim in the use of FSH should be obtaining a single live birth by a single follicular development. Potential risks of ovulation induction with FSH include ovarian hyperstimulation syndrome (OHSS) and multiple pregnancies. Ovaries of patients with PCOS are over-sensitive to the effects of FSH and therefore a low dose step-up protocol is recommented. ${ }^{5,8}$

In our study, we aim to compare the treatment success and complication rates of clomiphene citrate (CC) and gonadotopins ( $\mathrm{r}-\mathrm{FSH}$ ) using low dose step-up protocol, which are the two most frequently used ovulation induction agents in patients with polycystic ovary syndrome (PCOS).

\section{MATERIAL AND METHODS}

In this study, the medical files of 138 patients diagnosed with PCOS who were referred to our infertility outpatient clinic with infertility were examined. The study was approved by the local ethics committee and written informed consent was obtained from all participants.

Patients aged 18-39 years with an infertility history of at least one year with the following inclusion criteria were enrolled in the study: Body mass index (BMI) between $18-30 \mathrm{~kg} / \mathrm{m}^{2}$; folliclestimulating hormone (FSH) levels $<15 \mathrm{mIU}$ on the 3rd day of the menstrual cycle; normal prolactin levels; normal uterine cavities; lack of any tubal pathology as ruled out by laparoscopy and hysterosalpingography; absence of any other medical problem, previous ectopic pregnancy, persistent ovarian cyst or endometrioma larger than $4 \mathrm{~cm}$ in size, unexplained vaginal bleeding and uterine myoma.

The diagnosis of PCOS was based on Rotterdam criteria after excluding other etiological factors. ${ }^{9}$ Two of the following three criteria were required to confirm the diagnosis of PCOS; oligoanovulation, clinical and/or biochemical findings of hyperandrogenism and sonographic evidence of polycystic ovaries. Diagnosis of anovulation was made by the history of oligomenorrhea or amenorrhea, serum progesterone level on the 21st day of the menstrual cycle and sonographic monitorization of follicular maturation. The criteria for polycystic ovarian morphology includes the presence of 12 or more follicles measuring between 2 and 9 $\mathrm{mm}$ in diameter and/or an increased ovarian volume of greater than $10 \mathrm{~cm}^{3}$. This presentation in one ovary sufficiently defines the polycystic ovary. ${ }^{9}$

Male partners all had a normal semen analysis according to World Health Organization criteria. ${ }^{10}$ In all patients, intrauterine insemination (IUI) was performed after sperm washing instead of using semen samples after coitus interruptus. Patients whose male partners had total motile sperm counts less than $10 \mathrm{million} / \mathrm{mL}$ were excluded from the study. 
Ovulation induction was started on patients following spontaneous or medroxyprogesterone acetate-induced (Farlutal, Deva Medical, Istanbul, Turkey) (10 mg/day, for 10 days) menses. Clomiphene citrate (CC) (Klomen, Kocak medical, Istanbul, Turkey) treatment was started at a daily dose of $50 \mathrm{mg} /$ day (oral) for 5 days from day 4 of a spontaneous or medroxyprogesterone acetate-induced menses. Oral dose is raised by $50 \mathrm{mg} /$ day up to $150 \mathrm{mg}$ in subsequent cycles if ovulation was not achieved. When the follicle is $\geq 17 \mathrm{~mm}, 10.000 \mathrm{IU}$ of HCG (Ovitrelle Merc-Serono, Italy) was applied intramuscularly to trigger ovulation.

If no growing follicle was seen until $18-20^{\text {th }}$ day, the cycle was cancelled.

TVUSG was used to monitor ovarian growth 4 days after the last CC dose and repeated every other day until ovarian activity was detected.

If no growing follicle was seen until 20-21 day, the cycle was cancelled.

Low-dose step-up protocol with a starting dose of 75 IU/day Recombinant Human FSH (Puregon, Schering-Plough, Houten, The Netherlands \& Gonal F, Merc-Serono S.A Aubonne Switzerland) s.c was used for ovulation induction in all cases for gonadotropin therapy on $3-4^{\text {th }}$ days of the cycle. Stimulation was continued with the same gonadotropin dose until the $14^{\text {th }}$ day in no follicle $\geq 10$ $\mathrm{mm}$ was detected in folliclometry performed on the $7^{\text {th }}$ of stimulation. If no adequate follicle development is observed, the dosage of r-FSH is increased by 37.5 IU/day. Dosage increases were repeated weekly until adequate follicular development. The dose, at which follicle development is observed ( $\geq 10 \mathrm{~mm})$, is continued and when the follicle is $\geq 17 \mathrm{~mm}, 10000$ IU of HCG (Ovitrelle MercSerono, Italy) was applied intramuscularly to trigger ovulation.

In the r-FSH cycles, TVUSG was performed weekly until ovarian activity was detected. After the detection, the frequency of sonography was increased to every other day or daily.

If estradiol levels are above $2000 \mathrm{pg} / \mathrm{mL}$ and/or more than 3 follicles $>14 \mathrm{~mm}$ were observed in
TVUSG, HCG was not applied and the cycle was canceled.

Intrauterine insemination (IUI) was performed 36 hours after HCG administration in both groups and intercourse was recommended every other day.

Menstruation 14 days after the HCG administration, or the detection of pregnancy when menstruation does not occur was considered as a clinical sign of ovulation.

In patients who do not have menstruation, serum $\beta$-HCG levels were measured 15 days after IUI for detecting pregnancy and values above 10 micro-IU/ml were considered as positive.

The cases which intrauterine gestational sac and cardiac activity was detected in follow-up were considered clinical pregnancy and the cases that go beyond $12^{\text {th }}$ gestational week were considered ongoing pregnancy.

Maximum two cycles of clomiphene and/or low-dose r-FSH treatment was given in both groups. When the therapy failed, patients were referred to the IVF clinic.

\section{STATISTICAL ANALYSIS}

For the statistical analysis of the study findings, NCSS 2007\&PASS 2008 Statistical Software (Utah, USA) was used. During evaluation of study data, in addition to descriptive statistical methods (mean; standard deviation) for the intergroup comparisons of quantitative data with normal distribution, Student's $t$ test was used. For intergroup comparisons of parameters showing heterogenous distribution, Mann-Whitney U test was employed. Qualitative data were compared using chi-square and Fisher's exact test. The results were evaluated within 95\% confidence interval and $\mathrm{p}$ values lesser than 0.05 were considered significant.

\section{RESULTS}

A total of 263 cycles of ovulation induction were performed on 138 patients. Demographic data for each group were shown in Table 1. Levels of FSH ranged between 3.10 and $10.7 \mathrm{mIU} / \mathrm{mL}$. Levels of 
FSH, LH, E2, TSH and FSH/LH ratios were not significantly different between the groups ( $\mathrm{p}>0.05$ ). However, prolactin levels were found to be significantly higher in the CC group when compared to the $\mathrm{r}-\mathrm{FSH}$ group $(\mathrm{p}<0.05)$. Mean prolactin values were $14.61 \pm 5.58$ in the clomiphene group and $13.33 \pm 4.68$ in the $\mathrm{r}-\mathrm{FSH}$ group. These values are within the normal acceptable range, do not require treatment and are considered not to have an effect on induction. Also, these values represent baseline hormone levels and are independent of both drug groups.

On pre-treatment baseline ultrasound (TVUSG) assessments, the number of antral follicles (AF) in the right ovaries ranged between 0 (none) and $12(4.75 \pm 2.28)$, while in the left ovaries they varied between 0 and 14 (4.66r2.289). Pre-treatment endometrial thickness was found to be between 2.1 and $12 \mathrm{~mm}(4.77 \pm 1.70 \mathrm{~mm})$. Baseline measurements of endometrial thickness did not demonstrate any statistically significant difference between groups ( $p>0.05)$. Pre-treatment baseline TVUSG did not reveal any significant intergroup differences as for the number of antral follicles in the right and the left ovaries $(p>0.05)$. Total motile sperm count measurements also did not demonstrate significant differences between groups $(\mathrm{p}>0.05)$.

The number of newly developed follicles showed statistically significant differences between groups $(\mathrm{p}<0.01)$. The number of follicles was found to be significantly higher in r-FSH group. The rates of anovulation and monofollicular maturation were higher in cases on CC therapy, while the rate of polyfollicular maturation was significantly higher in r-FSH users. Number of cycles did not differ between groups $(\mathrm{p}>0.05)$. Average number of total follicles were found to be significantly higher in the $r-F S H$ group $(p<0.01)$. Rates of ovulation in the r-FSH and anovulation in the CC group were significantly higher $(\mathrm{p}<0.05)$ (Table 2). Duration of r-FSH therapy ranged between 3 and 25 days $(10.95 \pm 4.61$ days $)$ and total dose administered per cycle varied between 225 and $2400 \mathrm{IU}(867.59 \pm 446.13 \mathrm{IU})$. Number of newly developed follicles varied between 0 and 8

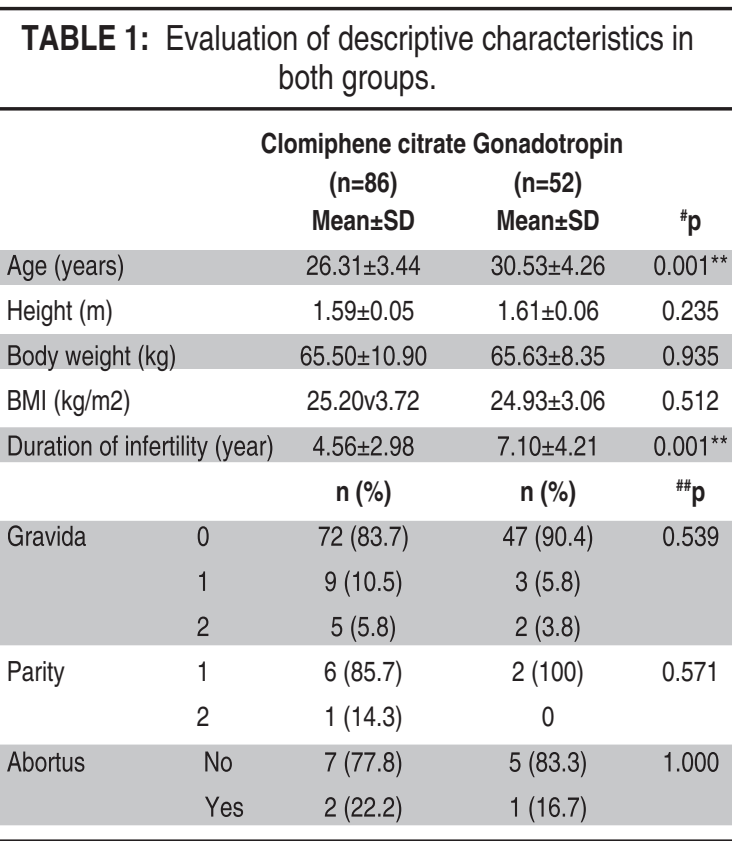

\#: Student's t test; \#\#: Chi-square test and Fisher's exact test; * ${ }^{*} p<0,01$. BMI: Body mass index.

TABLE 2: Assessment of total number of cycles, follicles, and rates of ovulation, and anovulation.

\begin{tabular}{|c|c|c|c|}
\hline & $\begin{array}{l}\text { miphene citrate } \\
\text { Mean } \pm S D \\
\text { (median) }\end{array}$ & $\begin{array}{c}\text { Gonadotropin } \\
\text { Mean } \pm S D \\
\text { (median) }\end{array}$ & $\# p$ \\
\hline Total number of cycles & $1.96 \pm 1.10$ & $\begin{array}{c}1.81 \pm 1.01 \\
(2.0)\end{array}$ & $\begin{array}{l}0.405 \\
(1.5)\end{array}$ \\
\hline Total number of follicles & $2.27 \pm 2.55$ & $\begin{array}{c}3.59 \pm 3.15 \\
(1.0)\end{array}$ & $\begin{array}{c}0.002^{* *} \\
(3.0) \\
t\end{array}$ \\
\hline $\begin{array}{l}\text { Number of } \\
\text { ovulations achieved }\end{array}$ & $100(74.1)$ & $110(85.9)$ & $0.017^{*}$ \\
\hline $\begin{array}{l}\text { Number of anovulatory } \\
\text { cycles }\end{array}$ & $35(25.9)$ & $18(14.1)$ & \\
\hline
\end{tabular}

": Mann Whitney U test; ${ }^{\dagger}:$ chi-square test; ${ }^{*} p<0,05 ;{ }^{* *} p<0,01$.

$(1.45 \pm 1.36)$. Coasting procedure was applied significantly more often in the $\mathrm{r}-\mathrm{FSH}$ group $(\mathrm{p}<0.05)$. A total of five patients used cetrorelix (Cetrotide, Sereno medical, Halle, Germany). Three patients of the r-FSH group underwent post-coasting IUI procedure and in two patients the cycles were cancelled. The incidence of OHSS did not differ between groups $(p>0.05)$. Only one patient in the r-FSH group developed a mild form of OHSS. This 
patient was hospitalized for one day and then she was monitorized and treated on an outpatient basis.

Distribution of IUI procedures demonstrated significant difference among groups $(\mathrm{p}<0.01)$ (Table 3). In r-FSH group, the incidence of IUI application and the number of cancelled IUIs due to occurrence of hyperstimulation were found to be significantly higher. However in the CC group, the incidence of spontaneous ovulation and the number of cancelled IUIs because of anovulation were higher. In cases of IUI, the rates of $\beta$-HCG positivity did not differ between groups $(\mathrm{p}>0.05)$ (Table 3).

Pregnancy rates in groups did not demonstrate any statistically significant difference $(\mathrm{p}>0.05)$. Pregnancy rates were found to be $12.5 \%$ and $5.9 \%$ in the r-FSH and CC groups, respectively. In the CC group ( $\mathrm{n}=8)$, pregnant patients delivered alive or still born (for both; $\mathrm{n}=1 ; 12.5 \%$ ) babies. One had a miscarriage at her $10^{\text {th }}$ gestational week, while the pregnancies of 5 women (62.5\%) were maintained. Besides, during follow-up period of one HCG-posi- tive patient after IUI, ectopic pregnancy was detected. This patient had undergone laparoscopic right salpingectomy. On the other hand, in the $\mathrm{r}-$ FSH group ( $\mathrm{n}=16$ pregnant patients) incidents of 6 live births (37.5\%), 1 stillbirth (6.3\%) and 2 miscarriages $(12.5 \%)$ at $10^{\text {th }}$ and $11^{\text {th }}$ gestational weeks were noted while 7 (43.8\%) women were still pregnant and 2 of them had multiple pregnancies (one with twin and the other triplet pregnancies). No significant intergroup difference was seen among types of childbirth ( $p>0.05$ ). Incidence of gestational complications did not differ between groups ( $>0.05)$. In the CC group, only one case (12.5\%) received in-patient treatment because of threatened abortus. In the r-FSH group, complications developed in 5 cases (35.7\%). One of these patients was hospitalized for treatment. One patient underwent cerclage operation at the sixth week of gestation because of cervical insufficiency. One patient developed gestational diabetes mellitus (GDM); her blood sugar was regulated with dietary intervention. Severe preeclampsia evolved in one patient and she received intravenous magnesium sulfate therapy

\begin{tabular}{|c|c|c|c|c|}
\hline & & $\begin{array}{c}\text { Clomiphene citrate } \\
\text { Mean } \pm S D \\
\text { (median) }\end{array}$ & $\begin{array}{l}\text { Gonadotropin } \\
\text { Mean } \pm S D \\
\text { (median) }\end{array}$ & $\# p$ \\
\hline \multirow[t]{3}{*}{ Number of developing follicles } & & $1,01 \pm 0,82$ & $1,92 \pm 1,69$ & $0.001^{* *}$ \\
\hline & & $(1,00)$ & $(1,00)$ & \\
\hline & & $n(\%)$ & $n(\%)$ & $t p$ \\
\hline \multirow[t]{3}{*}{ Follicle } & Anovulation & $35(25.9)$ & $18(14.1)$ & $0.001^{* *}$ \\
\hline & Monofollicular & $71(52.6)$ & $47(36.7)$ & \\
\hline & Polyfollicular & $29(21.5)$ & $63(49.2)$ & \\
\hline \multirow[t]{2}{*}{ Ovulation with HCG } & Yes & $42(31.1)$ & $28(21.9)$ & 0.090 \\
\hline & No & $93(68.9)$ & $100(78.1)$ & \\
\hline Coasting & (Cetrorelix) & $0(0.0)$ & $5(3.9)$ & $0.026^{*}$ \\
\hline \multirow[t]{2}{*}{ OHSS } & Yes (mild) & $0(0.0)$ & $1(0.8)$ & 0.487 \\
\hline & None & $135(100)$ & $127(99.2)$ & \\
\hline \multirow[t]{4}{*}{ IUI procedure } & Yes & $92(68.1)$ & $100(78.1)$ & $0.001^{* *}$ \\
\hline & No (Hyperstimulation) & $1(0.7)$ & $9(7.0)$ & \\
\hline & No (Spontaneous ovulation) & $6(4.4)$ & $1(0.8)$ & \\
\hline & No (Anovulation) & $36(26.7)$ & $18(14.1)$ & \\
\hline \multirow[t]{2}{*}{ Beta HCG } & Positive & $9(9.2)$ & $16(15.8)$ & 0.157 \\
\hline & Negative & $89(90.8)$ & 85 (84.2) & \\
\hline
\end{tabular}

\#: Mann-Whitney U test; ${ }^{\dagger}$ : chi-square test, and Fisher's exact test; ${ }^{* *} p<0,01$.

OHSS: Ovarian Hyper Stimulation Syndrome; IUI: Intra Uterine Insemination. 
before and after delivery. Placenta previa totalis was observed in one patient and she was referred to our hospital with vaginal bleeding (Table 4).

\section{DISCUSSION}

CC has been used as a first-line treatment of infertility for many years. It has a favorable cost-effectiveness, its oral use increases patient compliance with relatively few side effects and it requires shorter follow-up period for the monitorization of ovarian response However, about $20 \%$ of women fail to ovulate in spite of increasing doses of this drug, up to $150 \mathrm{mg}$ daily, like obese (BMI>30) and insuline resistance. ${ }^{11,12}$ The maximum number of cycles is generally limited to six ovulatory cycle ${ }^{5}$.

Ovulation induction with gonadotropins is considered to be among second line therapies for ovulation induction by the ESHRE/ASRM ${ }^{5}$. Despite the high risk of side effects and high costs, gonadotropin administration is accepted widely in PCOS patients. ${ }^{5,13}$

In low dose step-up method for the induction of follicular maturation, the concept of threshold dose, which constitutes the main principle of lowdose step-up method, is important. Accordingly each follicle reacts only to FSH doses over a certain threshold dose. Under this dose, its development cannot be induced, while FSH dose well above this threshold causes the development of multiple follicles. This threshold dose varies among patients and among individual cycles of a single patient. ${ }^{14}$

For the first time; Brown reviewed induction of ovulation with low-dose FSH; where FSH was initiated at a lower dose with small increments in dosage. ${ }^{15}$ These researchers increased FSH dosage at a rate of $10-30 \%$ every 5 days and achieved monofollicular development and higher levels of E2. They reported that higher increments in dosages with shorter intervals might result in multifollicular development, OHSS and multiple pregnancies.

Homburg and Howles described 75 IU/day step up FSH protocol regimens for women with PCOS; starting with a daily dose of 75 IU for 14 days, using incremental dose rises when necessary, and inducing uni-ovulation in $\% 70$ cycles. ${ }^{16}$

Balasch et al. compared the outcomes of initiating low-dose step-up recombinant human FSH treatment protocol with $37.5 \mathrm{IU}$ or $50 \mathrm{IU}$. Average duration of treatment was detected to be 13 days

\begin{tabular}{|c|c|c|c|c|}
\hline & & $\begin{array}{c}\text { Clomiphene citrate } \\
n(\%)\end{array}$ & $\begin{array}{c}\text { Gonadotropin } \\
n(\%)\end{array}$ & \#p \\
\hline \multirow[t]{2}{*}{ Pregnancy } & Yes & $8(5.9)$ & $16(12.5)$ & 0.064 \\
\hline & No & $127(94.1)$ & $112(87.5)$ & \\
\hline \multirow[t]{4}{*}{ Birth $(n=24)$} & Live birth & $1(12.5)$ & $6(37.5)$ & 0.622 \\
\hline & Stillbirth & $1(12.5)$ & $1(6.3)$ & \\
\hline & Abort & $1(12.5)$ & $2(12.5)$ & \\
\hline & Maintenance of Pregnancy & $5(62.5)$ & $7(43.8)$ & \\
\hline \multirow[t]{6}{*}{ Gestational complications } & Abortus Imminens & $1(12.5)$ & $1(6.3)$ & 1.000 \\
\hline & Gestational diabetes mellitus & 0 & $1(6.3)$ & \\
\hline & Cerclage & 0 & $1(6.3)$ & \\
\hline & Preeclampsia & 0 & $1(6.3)$ & \\
\hline & Plasenta previa previous S/C & 0 & $1(6.3)$ & \\
\hline & None & $7(87.5)$ & $11(68.8)$ & \\
\hline \multirow[t]{2}{*}{ Types of delivery } & Normal spontaneous vaginal delivery & $1(50.0)$ & $4(57.1)$ & 1.000 \\
\hline & Cesarean section & $1(50.0)$ & $3(42.9)$ & \\
\hline
\end{tabular}

t: chi-square test 
in both groups, while significantly shorter durations of treatment were noted in the group where treatment was started with total gonadotrophin dose of $37.5 \mathrm{IU}$ per patient. The authors found initiation of therapy at a FSH dose of 37.5 IU was more appropriate. ${ }^{17}$

In a prospective randomized study by Leader performed to achieve monofollicular development in WHO group II anovulatory patients, the starting dosage of r-FSH was 50 IU/day for 7 days. In the absence of follicles $>$ or $=12 \mathrm{~mm}$, the daily dosage was increased by either 25 or 50 IU per week. As a result they found weekly increments of $25 \mathrm{IU}$ in the daily dose were more effective and efficient than $50-\mathrm{IU}$ increments. ${ }^{18}$

In our study, the treatment was started with a dose of 75 IU r-FSH and an average duration of treatment was estimated to be 10.9 days. A total FSH dose of 867.5 IU was administered for each patient in every cycle.

Lopez et al. performed a randomized controlled study with 76 infertile PCOS patients (38 patients in each arm) where they compared the effectiveness of CC and r-FSH. At the end of the study, cumulative rates of pregnancy were $43 \%$ in the FSH and 24\% in the CC groups. The RR and $\% 95$ confidence intervals were 1.78 for pregnancy rate per woman and 1.83 for live births per woman in $\mathrm{r}$-FSH group. The authors indicated that as a first-line therapy, low-dose FSH might replace CC in the treatment of anovulatory PCOS. ${ }^{19}$

In our study, number of follicles developed was significantly higher in r-FSH group $(\mathrm{p}=0.001)$. Pregnancy rates per cycle were found to be $5.9 \%$ in the CC and $12.5 \%$ in the r-FSH groups. $(\mathrm{p}=0.064)$. Live birth rates and ongoing pregnancy rates did not show a significant difference $(\mathrm{p}=0.62)$. In the CC group higher rates of anovulation (25.9\%) and monofollicular development (71\%) were noticed relative to the r-FSH group (corresponding rates were 14.1 and $47 \%$ in the $\mathrm{r}-\mathrm{FSH}$ group). In compliance with these and literature findings two $(1.5 \%)$ patients with multiple pregnancies (one with twin and the other with triplet pregnancies) were in the r-FSH group.
In a multinational study by Homburg et al., which includes 302 patients with PCOS, ovulation induction (per-protocol) with FSH was higher clinical pregnancy than with CC (58\% versus $44 \%$ (95\% Confidence Interval 1.5-25.8, $\mathrm{p}=0.03$ ) or a live birth 52\% versus 39\% (95\% Confidence Interval 0.4-24.6, $\mathrm{p}=0.04$ ) Also ovulation induction with FSH was associated with a higher pregnancy rate per cycle $[26.4 \%$ vs. $17.4 \%$ (95\% CI $2.4-15.6$, $\mathrm{p}=0.008)]$, and there was no significantly differences between ectopic pregnancy, miscarriage rate per pregnancy. Also, multiple pregnancies was not observed in the CC group but it was seen in 2 patients of the FSH group (3.4\%) (twins only). ${ }^{20}$

In our study, 2 cases of multiple pregnancies (1.5\%) were observed in r-FSH group (one couplet, one triplet), where there was no multiple pregnancy in CC group.

In our clinical study, multiple pregnancies were not encountered after induction of ovulation with CC, contrary to a $6 \%$ incidence reported by Legro et al. ${ }^{21}$

In our study, ovulation rates were $74.1 \%$ in the CC and $85.9 \%$ in the r-FSH group. Palomba et al. and in a separate study Moll et al. reported their ovulation rates in CC users as $67 \%$ and $72 \%$, respectively. ${ }^{22,23}$

In our study, one patient of the r-FSH group developed mild OHSS. This patient was hospitalized for one day and then she was monitorized and treated on an outpatient basis. In their study of PCOS patients treated with low dose step-up protocol, Hamburg and Howles reported the rate of OHSS to be $0.14 \% .{ }^{16}$ Lopez et al. observed mild OHSS in two subjects in their r-FSH group, both of which were pregnant. ${ }^{19}$

In our study, rate of miscarriage after first trimester of pregnancy was $12.5 \%$ in both groups, which is in compliance with literature findings. Though without any statistical significance, greater number of gestational complications (threatened abortion, GDM, preeclampsia, etc.) was detected in the gonadotropin group, which was attributed to the presence of relatively older women in this group. 


\section{CONCLUSION}

As a concluding remark derived from this study, CC has led to pregnancy rates close to those achieved by r-FSH, lower rates of OHSS and multiple pregnancies, and was associated with higher cost-effectiveness, easier monitorization (oral-use) and user- friendliness. On the other hand, low dose step up r-FSH protocol was found to be as safe as CC with PCOS patients. Thus, it can be used as a first- line treatment for PCOS who fail to ovulate with maximum doses of CC or to conceive for six or more cycles.

\section{Acknowlegements}

We wish to thank Dr Gulsah İlhan, Doğukan Anğın for help with performing statistical analysis.

\section{REFERENCES}

1. Speroff L, Glass RH, Kase NG. Anovulation and the Polycystic Ovary. Clinical Gyneacologic Endocrinology and Infertility. $1^{\text {st }}$ ed. Baltimore: Lippincott Williams \& Wilkins; 1973. p.256-57.

2. Kaya C, Cengiz SD, Berker B, Demirtaş S, Cesur M, Erdoğan G. Comparative effects of atorvastatin and simvastatin on the plasma total homocysteine levels in women with polycystic ovary syndrome: a prospective randomized study. Fertil Steril 2009;92(2):635-42.

3. Teede H, Deeks A, Moran L. Polycystic ovary syndrome: a complex condition with psychological, reproductive and metabolic manifestations that impacts on health across the lifespan. BMC Med 2010;8:41.

4. Brassard M, AinMelk Y, Baillargeon JP. Basic infertility including polycystic ovary syndrome. Med Clin North Am 2008;92(5):1163-92.

5. Thessaloniki ESHRE/ASRM-Sponsored PCOS Consensus Workshop Group. Consensus on infertility treatment related to polycystic ovary syndrome. Fertil Steril 2008;89(3):505-22

6. Balen AH. Ovulation induction in the management of anovulatory poly-cystic ovary syndrome. Mol Cell Endocrinol 2013;373(1-2): 77-82.

7. Gianaroli L, Racowsky C, Geraedts J, Cedars M, Makrigiannakis A, Lobo R. Best practices of ASRM and ESHRE: a journey through reproductive medicine. Hum Reprod 2012; 27(12):3365-79.

8. Christin-Maitre S, Hugues JN; Recombinant FSH Study Group. A comparative randomized multicentric study comparing the step-up versus step-down protocol in polycystic ovary syndrome. Hum Reprod 2003;18(8):1626-31.

9. Rotterdam ESHRE/ASRM-Sponsered PCOS Consensus Workshop Group. Revised 2003 consensus on diagnostic criteria and longterm health risks related to polycystic ovary syndrome. Fertil Steril 2004;81(1):19-25.
10. World Health Organization. WHO Laboratory Manual for the Examination o Human Semen and Sperm-Cervical Mucus Interaction. 4thed. Cambridge, UK; New York, NY: Published on behalf of the World Health Organization [by] Cambridge University Press; 1999. p.1-128.

11. Goodarzi MO, Dumesic DA, Chazenbalk G, Azziz R. Polycystic ovary syndrome: etiology, pathogenesis and diagnosis. Nat Rev Endocrinol 2011;7(4):219-31.

12. van Wely $M$, Bayram $N$, Bossuyt $P$, van der Veen F. Laparoscopic electrocautery of the ovaries versus recombinant FSH in clomiphene citrate-resistant polycystic ovary syndrome. Impact on women's health-related quality of life. Hum Reprod 2004;19(10):224450.

13. Beall SA, DeCherney A. History and challenges surrounding ovarian stimulation in the treatment of infertility. Fertil Steril 2012;97(4):795-801.

14. Hamilton-Fairley D, Kiddy D, Watson $H$, Sagle M, Franks S. Low dose gonadotropin therapy for induction of ovulation in 100 women with polycystic ovary syndrome. Hum Reprod 1991;6(8):1095-9.

15. Brown JB. Pituitary control of ovarian functionconcepts derived from gonadotrophin therapy. Aust N Z J Obstet Gynaecol 1978;18(1):4654.

16. Homburg R, Howles CM. Low-dose FSH therapy for anovulatory infertility associated with polycystic ovary syndrome; rationale, results, reflections and refinements. Hum Reprod Update 1999;5(5):493-9.

17. Balasch J, Fábregues F, Creus M, Casamitjana R, Puerto B, Vanrell JA. Recombinant human follicle-stimulating hormone for ovulation induction in polycystic ovary syndrome: a prospective, randomized trial of two starting doses in a chronic low-dose step-up protocol. J Asist Reprod Genet 2000;17(10):561-5.
18. Leader A. Monofollicular Ovulation Induction Study Group. Improved monofollicular ovulation in anovulatory or oligo-anovulatory women after a low-dose step-up protocol with weekly increments of 25 international units of follicle-stimulating hormone. Fertil Steril 2006;85(6):1766-73.

19. Lopez E, Gunby J, Daya S, Parilla JJ, Abad L, Balasch J. Ovulation induction in women with polycystic ovary syndrome: randomized trial of clomiphene citrate versus low-dose recombinant FSH as first line therapy. Reprod Biomed Online 2004;9(4):382-90.

20. Hamburg R, Hendriks ML, König TE, Anderson RA, Bale AH, Brincat M, et al. Clomifene citrate or low-dose FSH for the first-line treatment of infertile women with anovulation associated with polycystic ovary syndrome: a prospective randomized multinational study. Hum Reprod 2012;27(2);468-73.

21. Legro RS, Barnhart HX, Schlaff WD, Carr BR Diamond MP, Carson SA; Cooperative Multicenter Reproductive Medicine Network. Clomiphene, metformin or both for infertility in the polycystic ovary syndrome. N Engl J Med 2007;356(6):551-66.

22. Palomba S, Orio $F \mathrm{Jr}$, Falbo A, Manguso $\mathrm{F}$, Russo T, Cascella $T$, et al. Prospective parallel randomized, double-blind, doubledummy controlled clinical trial comparing clomiphene citrate and metformin as the firstline treatment for ovulation induction in nonobese anovulatory women with polycystic ovary syndrome. J Clin Endocrinol Metab 2005;90(7):4068-74.

23. Moll E, Bossuyt PM, Korevaar JC, Lambalk $\mathrm{CB}$, van der Veen F. Effect of clomifene citrate plus metformin and clomifene citrate plus placebo on induction of ovulation in women with newly diagnosed polycystic ovary syndrome: randomised double blind clinical trial. BMJ 2006;332(7556):1485. 